\title{
SIMULTANEOUS MEASUREMENTS OF THE BLOOD VOLUME IN MAN AND DOG BY MEANS OF EVANS BLUE DYE, T1824, AND BY MEANS OF CARBON MONOXIDE. I. NORMAL SUBJECTS ${ }^{1}$
}

\author{
BY JAMES HOPPER, JR.,2 HERBERT TABOR, AND ALEXANDER W. WINKLER \\ (From the Department of Internal Medicine, Yale University School of Medicine, and from the Medical \\ Service of the New Haven Hospital, New Haven)
}

(Received for publication September 20, 1943)

The volume of the circulating blood may, in principle, be estimated indirectly by determining the apparent volume of distribution of any substance which, upon being introduced into the circulation, does not escape from the vascular bed. All substances which have proven in any way suitable for this purpose fall into one or another of two main classes. Those of one group, such as certain dyes, are distributed mainly through the plasma, and measure plasma volume only. The most desirable dyes, such as T1824, are attached to the serum albumin (1). Those of the second group, such as carbon monoxide and radioactive iron (2), are confined mainly within the erythrocytes. This second group of substances therefore measures, primarily, cell volume. Although these substances are distributed through entirely different compartments of the total blood volume, it is possible to calculate the plasma volume from the cell volume and vice versa, if the fraction of cells in the circulating blood is simultaneously determined. It is therefore possible to measure whole blood volume by either method, and to compare the results. Were all assumptions implicit in their use correct, identical values for cell and plasma volumes should result. Any discrepancy between the values obtained by these two methods necessarily means that the assumptions underlying at least one of these methods are in error. On the other hand, the reverse proposition does not hold; to obtain identical numerical results by the two methods does not necessarily imply that they are both measuring true blood volume.

1 Aided by a grant from the Fluid Research Fund, Yale University School of Medicine, and from the Ella Sachs Plotz Fund.

2 Alexander Brown Coxe Fellow, 1941-1942, and American College of Physicians Fellow 1942-1943.
In the present study, simultaneous estimations of blood volume by the blue dye, T1824, ${ }^{8}$ and by carbon monoxide have been made in the dog and in man. The third variable, relative red blood cell volume, was measured by means of the hematocrit. Only results obtained in normal subjects are included in this paper; those in pathological subjects are presented in the following paper (3). Such simultaneous or nearly simultaneous measurements have only rarely been made (4 to 10), and very seldom with satisfactory modern technics. Yet coincidence of measurement is an absolute necessity if anything but a rough comparison of the two methods is to be attempted, since blood volume may change distinctly in the time elapsing between successive determinations. Temperature change, variation in the degree of physical relaxation, and a variety of nervous and hormonal effects are all known to influence blood volume markedly. Simultaneous measurement obviates difficulties due to the interplay of these influences.

\section{MATERIAL AND METHODS}

The group of human subjects studied was made up almost entirely of laboratory technicians, medical students, and physicians. All had normal blood pressures and normal serum protein concentrations. All subjects were in a post-absorptive state, as nearly basal as circumstances would allow. They were recumbent during the experiments.

The dogs were of mixed breed, in a good state of nutrition, and all but 2 were females. The splenectomized animals were not used until at least 2 or 3 weeks after the operation. Studies were done from 12 to 18 hours after the last feeding. Experiments were conducted with the animal upon its back strapped to an animal board. Some of the animals (Table III) were anesthetized with "Dial," $0.6 \mathrm{cc}$. per $\mathrm{kgm}$., and a tracheal cannula inserted through

The blue dye, T1824, was furnished by the Warner Institute for Therapeutic Research, New York City. 
which carbon monoxide was administered. It is to be noted that the effect of "Dial" on the spleen $(11,12)$ would not invalidate a comparison of the two methods done simultaneously. A constant temperature room was not used; however, room temperature was always recorded, and rarely varied more than 1 or 2 degrees during any single experiment.

Fasting samples for dye and carbon monoxide blanks and for hematocrit determinations were always taken initially. The dye was then given. Ten minutes later, a blood sample was taken for determination of the dye. The carbon monoxide was usually given immediately after the taking of this sample, although sometimes it was given immediately after giving the dye. A blood sample was taken for carbon monoxide analysis, 15 to 20 minutes after beginning the inhalation of the carbon monoxide. Further hematocrit determinations were frequently made.

Relative cell volume was measured in quadruplicate upon anaerobically defibrinated blood, by a method described by Eisenman (13), using calibrated Daland microhematocrit tubes. This method of defibrinating blood avoids the error produced by various anti-coagulants which may cause swelling or shrinkage of cells. The results are entirely reproducible, and apparently give the true relative cell volume, as indicated by Eisenman, MacKenzie, and Peters (14).

\section{USE OF DYE}

Plasma volumes were determined by the method of Gibson and Evelyn (15), using an Evelyn micro-photoelectric colorimeter. Readings were always made with serum at a depth of $10 \mathrm{~mm}$. The " $K$ " values and the "L540, L620" ratios for the lot of dye and for the particular machine used were determined $(15,16)$. All serum samples were examined, using first a 620 and then a 540 filter; whenever hemolysis was found, a correction was applied, as suggested by Gibson and Evelyn (15). In man, hemolysis was very rare; in the dog, not uncommon. If hemolysis was excessive, the entire blood volume study was discarded.

The precautions used in the handling of blood have been in part described elsewhere. Blood was taken with minimal stasis into oiled syringes. Serum samples for the determination of dye were spun twice, separated, and read in the colorimeter as soon as possible after the blood was drawn, usually within 1 hour. Phillips (17) has observed that under certain circumstances, dyed serum becomes decolorized on standing; therefore, it is desirable not to allow it to stand.

Ten minutes were allowed for mixing of the dye (33). Although disappearance curves were determined in many instances, all plasma volumes here given are, in the interest of simplicity, arbitrarily calculated from the concentration of the dye found in the 10-minute sample. Extrapolation of dye concentration back to the time of injection was not attempted. The uncertainty in distinguishing between mixing time and effects of dye loss makes this procedure also an arbitrary one." Therefore, it is not clear that extrapolation results in any greater precision of measurement.

It should be clearly understood that this single point method of calculating blood plasma volume necessarily always gives larger plasma volumes than do extrapolation methods, since the latter use a calculated figure for initial concentration of dye which is higher than the measured concentration after 10 minutes. This systematic difference amounts to some 5 to 10 per cent, and probably accounts for the fact that our values for plasma volume by the dye method slightly exceed those obtained by Gibson and Evans (19).

In some cases, multiple injections of dye were given. Under these circumstances, the presence of the residual dye was compensated for by the method of Gibson and Evelyn (15). A center setting was obtained, using the initial sample containing only old dye remaining from the preceding tests. The samples containing new as well as old dye were read against this center setting as a blank. The objection by Price and Longmire (16), that this method does not take into account continuing disappearance of original dye, becomes unimportant when only a brief 10-minute mixing time is used, since there is little further loss of the original dye in this time.

A single lot of 0.2 per cent stock T1824 in 0.85 per cent saline and a single calibrated syringe were used for all of the determinations. A $10 \mathrm{cc}$. aliquot of dye was injected during 30 or 40 seconds; blood was drawn back and forth into the syringe 2 or 3 times in order to insure complete delivery of the dye. If it was desired to give less dye, an initial dilution with physiological saline was made. The error in delivery approximated as much as $0.1 \mathrm{cc}$., representing a 1 per cent error. In dogs, the dye was always given into a dorsal forearm vein, where extravasation was readily detected. Blood for the determination of dye concentration was always taken with a needle other than that with which the dye was given, at a site remote from the site of injection. In human subjects, it was always

\footnotetext{
- King, Cole, and Oppenheimer (18) suggest a method for plotting the curve of dye disappearance based upon the fact that the loss of dye is proportional to the square root of time after injection. This method of plotting dye disappearance gives a somewhat more precise mathematical definition to the location of the extrapolated curve than does the linear extrapolation method. However, this square root extrapolation method of plotting dye concentration, like any other extrapolation method, depends for its validity upon the assumption that the loss of dye during the mixing time can be determined from a study of the later part of the disappearance curve. This assumption is highly conjectural, as is the assumption that the dye is not distributed into a space much larger than the vascular compartment, even during mixing time. This problem is further considered elsewhere (3). We therefore believe that the use of the dye concentration after 10 minutes gives results at least as accurate as those obtained by any of the extrapolation methods, and avoids the introduction of unwarranted assumptions.
} 
taken from the opposite arm; when repeated samples of blood were taken, the needle was left in place, as described by Gibson and Evans (19).

Carbon monoxide was not found to produce any discernible effect upon the dye disappearance curves, whether given before or after the 10-minute dye sample. Also, the color of plasma containing no dye was found to be unaffected by the giving of carbon monoxide.

\section{USE OF CARBON MONOXIDE}

In the course of preliminary experiments with technic, direct intravenous administration of carbon monoxide was tried both in dogs and in human beings. Van Slyke (20) mentions that it may be given intravenously, but apparently this mode of administration has seldom been attempted, although recently oxygen has been given in this manner (21). It was hoped that intravenous administration might be of especial advantage in animals and in patients, such as severe cardiac subjects, who for some reason could not tolerate a mask. Intravenous administration, however, did not eliminate the need for a mask since large amounts of carbon monoxide almost immediately appeared-in the expired air. It was, therefore, necessary to use a mask and a system for collecting all expired air, in order to measure the amount of carbon monoxide lost by this route. As much as 20 per cent of the carbon monoxide may be lost by way of the lungs during the process of administration. Also, too rapid administration results in discomfort to the patient, causing both coughing and substernal pain. With slow administration, these symptoms did not occur. Work on this method of administering carbon monoxide is continuing.

The carbon monoxide method for determination of blood volume used in the present study consists of $(a)$ administration of a small, measured non-toxic amount of carbon monoxide to the subject by means of a closed respiratory system, and (b) measurement of the change in concentration of carbon monoxide in the blood stream. The blood volume $(c)$ is then estimated from the extent to which the absorbed carbon monoxide is diluted.

\section{(a) Administration of carbon monoxide}

Measurement of the amount of carbon monoxide absorbed requires a knowledge of the purity of stock carbon monoxide, of the exact amount of this gas introduced into the closed respiration system, and of the amount of unabsorbed carbon monoxide left in the system after rebreathing.

Purity of stock carbon monoxide. The oxygen and carbon dioxide in stock gas were measured by means of a Haldane apparatus. From the volume of oxygen, the volume of nitrogen was estimated on the assumption that the only contaminant was room air containing these gases in the usual proportion. The contaminating air can be measured with an error not exceeding $\mathbf{0 . 0 0 2} \mathrm{cc}$. in $10 \mathrm{cc}$. of total gas.

Carbon monoxide gas was prepared by the action of sulfuric acid on formic acid (22). The carbon monoxide was first passed through a 10 per cent solution of sodium hydroxide to remove carbon dioxide and sulfides. It was then stored under positive pressure over 5 per cent sodium hydroxide, free of carbon dioxide. The pressure bottle was kept filled to the top with the alkaline solution covered by a layer of oil and was stoppered when not in use. Stored in this way the gas retained its purity well, changing by no more than 1 per cent per week.

Measurement of the gas administered. The apparatus for the administration of carbon monoxide was essentially that of Chang and Harrop (23). It consisted of a 5 liter rubber bag with 2 openings, a narrow one for the introduction of carbon monoxide and oxygen from the burette, and a wide one connected to a $500 \mathrm{cc}$. soda lime canister. The canister in turn was packed in ice to prevent undue heating, and was connected by a short wide tube to the mouthpiece. Just before the rebreathing period, a noseclip was applied. The small volume of this apparatus favored the absorption of carbon monoxide, since the absorption of carbon monoxide in the lungs is facilitated by a low oxygen tension (24). Carbon monoxide was introduced into this system from a water jacketed burette, with an error in measurement not exceeding 1 part in $\mathbf{5 0 0 .}$

Measurement of unabsorbed carbon monoxide after rebreathing. The amount of carbon monoxide left in the apparatus was quite variable, but was often a significant fraction of the amount originally introduced. The concentration of carbon monoxide remaining in an aliquot of gas was determined by the palladium method of Wennesland (25). Recovery by this method is not quite complete $(25,26)$, but the error does not exceed 5 per cent. The maximum error would not change the amount of residual carbon monoxide by more than $0.1 \mathrm{cc}$., which in turn corresponds to the insignificant error of 1 part in 1000 in the measurement of the total carbon monoxide absorbed. The cause of this low recovery is obscure; it is not due to loss of carbon monoxide in the interval between addition of sulfuric acid to blood and the coupling of the flasks. The rebreathing bag and pulmonary space were assumed to have a volume of $4500 \mathrm{cc}$. in man (23) and $2500 \mathrm{cc}$. in the dog. Total residual carbon monoxide was obtained by multiplying the concentration of gas by this volume. A considerable error in the estimation of residual carbon monoxide results in much less of an error in the estimation of blood volume. For example, the maximum error in the measurement of blood volume due to differences among triplicate chemical analyses of the residual gas was $0.4 \pm 0.5$ per cent in 12 sets of analyses in human subjects and $1.53 \pm 0.41$ per cent in 53 sets of analyses in dogs.

\section{(b) Measurement of change in concentration of carbon monoxide in blood}

Blood for analysis was defibrinated anaerobically over mercury (13). Two methods for the measurement of carbon monoxide content were used, that of Sendroy and Liu (27) and that of Wennesland (25). The latter depends on the ability of carbon monoxide to reduce palladium chloride. The error of this palladium method, in 78 sets of triplicate analyses of blood obtained after carbon monoxide inhalation, was $0.060 \pm 0.040$ volumes per cent of gas; the greatest individual difference from the average of the 3 determinations was $0.034 \pm 0.025$ volumes per 
cent. The error in 46 sets of triplicate analyses of blood taken before inhalation of carbon monoxide was almost the same, $0.045 \pm 0.044$ volumes per cent of carbon monoxide; the greatest single difference from the average of 3 was $0.023 \pm 0.015$ volumes per cent. Since, therefore, the error in the palladium method is an absolute one, the percentage error decreases with increasing concentration of carbon monoxide.

In Table I, 13 sets of simultaneous analyses with both methods are compared. The palladium analyses were done in triplicate, those by the method of Sendroy and Liu either in duplicate or in triplicate. The 2 methods in our hands evidently gave substantially equal results. This is contrary to the experience of Wennesland, who failed to obtain as complete recovery of carbon monoxide from blood with the palladium method as with that of Sendroy and Liu. To make the values equal, he applied a constant correction factor of 1.04 to his palladium figures. From his own data, however, there is evidence that the proper factor is not a constant but a variable, and that at low concentrations of carbon monoxide, it is unity. In his Table VI, only 1 of 4 analyses of 2 blood samples with a low carbon monoxide content (samples 3 and 4) is improved by the use of his correction factor of 1.04 ; the other 3 are either not improved or are made worse (Samples 1 and 2 are admittedly inaccurate because of excess agitation). With blood specimens containing more carbon monoxide, the correction factor of 1.04 is approximately correct; in 242 determinations (Table III), the average correction factor is 1.0375, and in 113 subsequent analyses (p. 63), the average correction factor is 1.043. Analyses of air samples containing even larger amounts of carbon monoxide, equal to that in blood samples half saturated with gas, require the still larger average correction factor of 1.508. His blood samples usually contained more carbon monoxide than did ours. This fact offers a possible explanation of the discrepancy between his results and ours,

TABLE I

Comparison between Sendroy method and palladium method on the recovery of carbon monoxide from blood

\begin{tabular}{|c|c|c|c|}
\hline \multirow{2}{*}{ Subject } & \multirow{2}{*}{$\begin{array}{l}\text { Date } \\
1942\end{array}$} & \multicolumn{2}{|c|}{ Carbon monoxide, volumes per cent } \\
\hline & & $\begin{array}{c}\text { Palladium } \\
\text { method }\end{array}$ & $\begin{array}{l}\text { Sendroy and Liu } \\
\text { method }\end{array}$ \\
\hline $\begin{array}{l}\text { Dog } 11 \\
\text { J.J.W. } \\
\text { D.G. } \\
\text { P.H. } \\
\text { B.K. } \\
\text { E.R. } \\
\text { Dog C } \\
\text { D.W.S. } \\
\text { M.S. } \\
\text { M.O. } \\
\text { S.J. } \\
\text { C.B. } \\
\text { H.S. }\end{array}$ & $\begin{array}{lr}\text { Sept. } & 24 \\
\text { Sept. } & 28 \\
\text { Oct. } & 5 \\
\text { Oct. } & 7 \\
\text { Oct. } & 8 \\
\text { Oct. } & 9 \\
\text { Oct. } & 13 \\
\text { Oct. } & 14 \\
\text { Oct. } & 16 \\
\text { Oct. } & 21 \\
\text { Oct. } & 22 \\
\text { Nov. } & 16 \\
\text { Nov. } & 9\end{array}$ & $\begin{array}{l}2.47 \\
1.66 \\
1.97 \\
3.07 \\
2.02 \\
2.13 \\
3.64 \\
1.76 \\
2.54 \\
2.30 \\
1.82 \\
2.08 \\
3.22\end{array}$ & $\begin{array}{l}2.49 \\
1.70 \\
1.93 \\
3.03 \\
1.93 \\
2.15 \\
3.62 \\
1.76 \\
2.51 \\
2.32 \\
1.81 \\
2.09 \\
3.22\end{array}$ \\
\hline & & Average 2.36 & Average 2.35 \\
\hline
\end{tabular}

if we assume that the low range of concentrations in our experiments is correlated with a correction factor too small to be significant.

\section{(c) Procedure and calculation of blood volume}

An initial $10 \mathrm{cc}$. sample of blood was taken from an antecubital vein without stasis. The mouthpiece and nose-clip were applied and 100 to $130 \mathrm{cc}$. of carbon monoxide were admitted to the bag. Oxygen was used to wash in the last traces of the carbon monoxide, and was thereafter supplied when needed. An attempt was made to leave as little oxygen in the bag at the end of the rebreathing period as was compatible with comfort in breathing. Rebreathing continued for 15 or 20 minutes, although absorption and mixing were actually complete in less than 15 minutes $(10,23)$. Before or within a minute after disconnecting the rebreathing system from the patient, a second $10 \mathrm{cc}$. blood sample was obtained. Samples of gas were then withdrawn from the rebreathing bag for analysis of their carbon monoxide content. The procedure in dogs was very similar, except that smaller amounts of carbon monoxide, 30 to $65 \mathrm{cc}$., were given. A mask, made of a funnel fitted with a piece of automobile inner tube and sealed around the dog's muzzle with crude petrolatum, was used.

Blood volume was calculated by the formula:

B.V.(cc.)

[(cc. of stock $\mathrm{CO}$ given)

$X$ (per cent $\mathrm{CO}$ in stock gas) ] - (cc. residual $\mathrm{CO}$ )

$\mathrm{CO}$ of second blood (cc. per cc.)

$-\mathrm{CO}$ of first blood (cc. per CC.)

\section{RESULTS}

The data from normal human subjects are presented in Table II, while those from normal and splenectomized dogs are presented in Table III. In the final columns of both tables are the ratios of blood volume by the dye method to blood volume by the monoxide method. Since the error of each method approximates 3 or 4 per cent, ratios falling between 0.95 and 1.05 are not certainly different from unity. In the human experiments (Table II), only 7 of 13 ratios fall within this range, 3 lying above and 4 below. In the dog experiments (Table III), the results are very similar; 8 fall within the range of equality, 6 fall above and 5 below. Occasional ratios differ from unity by an amount much exceeding any possible experimental error. In 2 of the human experiments and in 7 of the dog experiments, the ratios fell below 0.90 or exceeded 1.10 . In summary, the 2 methods gave virtually identical results in about half the individual instances, while in the remainder they differed. 
TABLE II

Blood volumes of normal human subjects, measured simultaneously by the use of carbon monoxide and by the use of Evans blue dye (T-1824)

\begin{tabular}{|c|c|c|c|c|c|c|c|c|c|}
\hline \multirow{3}{*}{ Subject } & \multirow{3}{*}{ Sex } & \multirow{3}{*}{ Age } & \multirow{3}{*}{ Weight } & \multirow{3}{*}{ Height } & \multirow{3}{*}{ Date } & \multirow{3}{*}{$\begin{array}{l}\text { Relative cell } \\
\text { volume }\end{array}$} & \multicolumn{2}{|c|}{ Total blood volume } & \multirow{3}{*}{$\begin{array}{l}\text { Ratio, } \\
2: 1\end{array}$} \\
\hline & & & & & & & 1 & 2 & \\
\hline & & & & & & & CO method & Dye method & \\
\hline & & years & kgm. & $\mathrm{cm}$. & \multirow{10}{*}{\begin{tabular}{lr}
\multicolumn{1}{c}{1942} \\
Sept. 14 \\
Oct. 22 \\
Sept. 21 \\
Oct. 21 \\
Sept. & 4 \\
Oct. & 7 \\
Sept. & 23 \\
Sept. & 12 \\
Oct. & 9 \\
Sept. & 28 \\
Oct. & 8 \\
Oct. & 14 \\
Sept. & 9
\end{tabular}} & \multirow{10}{*}{$\begin{array}{c}\text { per cent } \\
38.0 \\
35.2 \\
46.4 \\
39.4 \\
39.3 \\
40.9 \\
40.3 \\
46.8 \\
45.8 \\
46.7 \\
47.5 \\
47.1 \\
47.9\end{array}$} & \multirow{10}{*}{$\begin{array}{c}c c . \\
5000 \\
4835 \\
3470 \\
3830 \\
3750 \\
3490 \\
5190 \\
5800 \\
5700 \\
6950 \\
5475 \\
6060 \\
5420\end{array}$} & \multirow{10}{*}{$\begin{array}{c}c c . \\
4530 \\
4600 \\
3730 \\
3600 \\
3740 \\
3565 \\
5200 \\
5310 \\
5350 \\
7800 \\
6330 \\
6100 \\
5640\end{array}$} & \multirow{10}{*}{$\begin{array}{l}0.91 \\
0.95 \\
1.08 \\
0.94 \\
1.00 \\
1.02 \\
1.00 \\
0.92 \\
0.94 \\
1.12 \\
1.16 \\
1.01 \\
1.04\end{array}$} \\
\hline S.J. & $F$ & & 57 & & & & & & \\
\hline M.O. & $\mathbf{F}$ & 20 & 47 & 168 & & & & & \\
\hline P.H. & $\mathbf{F}$ & 40 & 55 & 153 & & & & & \\
\hline D.H. & $\mathrm{F}$ & 31 & 68 & 178 & & & & & \\
\hline E.R. & $\mathrm{M}$ & 23 & 66 & 179 & & & & & \\
\hline I W & $M$ & 23 & 78 & 188 & & & & & \\
\hline B.K. & $\mathbf{M}$ & 30 & 80 & $\begin{array}{l}100 \\
176\end{array}$ & & & & & \\
\hline D.S. & $\mathrm{M}$ & 22 & 63 & 182 & & & & & \\
\hline E.H. & $\mathbf{M}$ & 42 & 69 & 175 & & & & & \\
\hline
\end{tabular}

Sometimes one and sometimes the other method gave the larger value. Partly, at least, as a consequence of this fact, average values for blood volume by the 2 methods, in terms of cc. per $\mathrm{kgm}$. body weight, were almost identical. This is shown in Table IV. All dogs were grouped together for the purpose of calculating the average value, since splenectomized dogs do not appear to differ significantly from normal ones with respect to the distribution of carbon monoxide and of the dye T1824 (Table III).

\section{DISCUSSION}

Other observers have compared blood volume measurements by the carbon monoxide method with those obtained by various dye methods (4 to 10). Since the conclusions reached by different workers are not entirely in agreement, either among themselves or with the results presented here, they will be briefly reviewed.

Asmussen (4) stands alone in stating, in a recent publication, that the carbon monoxide method gives consistently larger values than does the Evans blue dye method. This conclusion is not, however, well supported by his own data. In the first place, in nearly half the determinations, the differences between the blood volume figures by the 2 methods do not, in fact, exceed those to be expected from the error of the methods used. Also, using Asmussen's own figures, it may be demonstrated that there is no significant statistical difference between the average of the blood volumes determined by the monoxide method and the average of those determined by

\section{TABLE III}

Blood volume of normal and splenectomized dogs, measured simultaneously by the use of carbon monoxide and by the use of Evans blue dye (T-1824)

\begin{tabular}{|c|c|c|c|c|c|c|}
\hline \multirow{3}{*}{ Dog* } & \multirow{3}{*}{ Weight } & \multirow{3}{*}{ Date } & \multirow{3}{*}{$\begin{array}{c}\text { Rela- } \\
\text { tive } \\
\text { cell } \\
\text { volume }\end{array}$} & \multicolumn{2}{|c|}{ Total blood volume } & \multirow{3}{*}{$\begin{array}{c}\text { Ratio, } \\
2: 1\end{array}$} \\
\hline & & & & 1 & 2 & \\
\hline & & & & method & $\begin{array}{c}\text { Dye } \\
\text { method }\end{array}$ & \\
\hline \multirow{5}{*}{$\begin{array}{l}1 \\
2 \\
3\end{array}$} & kgm. & 1943 & per cent & $c c$. & $c c$. & \multirow{17}{*}{$\begin{array}{c}0.84 \\
(0.72) \\
1.01 \\
1.05 \\
0.84 \\
1.06 \\
0.98 \\
1.13 \\
1.05 \\
0.98 \\
0.98 \\
1.14 \\
1.03 \\
0.97 \\
1.16 \\
1.06 \\
1.13\end{array}$} \\
\hline & 14.6 & Tan. & 57.1 & 1590 & 1330 & \\
\hline & 12.7 & Jan. 28 & 45.2 & 1100 & $(794) \ddagger$ & \\
\hline & 8.5 & Feb. 9 & 44.4 & 965 & 979 & \\
\hline & 8.5 & Feb. 24 & 41.3 & 890 & 934 & \\
\hline 4 & 8.5 & Feb. 15 & 32.0 & 950 & 800 & \\
\hline 5 & 6.5 & Mar. 4 & 46.6 & 660 & 700 & \\
\hline 6 & 9.6 & May 10 & 47.4 & 960 & 940 & \\
\hline 7 & 28.1 & Jan. 25 & 49.5 & 2350 & 2650 & \\
\hline $\begin{array}{l}8 \\
0\end{array}$ & 115 & Feb. $17 f$ & $\begin{array}{l}40.7 \\
500\end{array}$ & $\begin{array}{r}719 \\
1200\end{array}$ & $\begin{array}{r}754 \\
1200\end{array}$ & \\
\hline S1 & 9.3 & Mar. 17 & $\begin{array}{l}39.0 \\
31.2\end{array}$ & $\begin{array}{r}1220 \\
854\end{array}$ & $\begin{array}{r}1200 \\
837\end{array}$ & \\
\hline & 9.5 & Mar. 29 & 29.5 & 800 & 912 & \\
\hline S2 & 6.8 & Apr. 15 & 38.0 & 560 & 576 & \\
\hline S3 & 6.3 & Apr. 15 & 38.4 & 675 & 654 & \\
\hline & 6.7 & Apr. $29 \dagger$ & 28.1 & 579 & 670 & \\
\hline \multirow[t]{2}{*}{ S4 } & 17.2 & May 6 & 40.8 & 1315 & 1395 & \\
\hline & 17.3 & May $12 \dagger$ & 41.3 & 1405 & 1590 & \\
\hline
\end{tabular}

* Prefix "S" indicates splenectomized animals.

$\uparrow$ Dial anesthesia, carbon monoxide administered by tracheal cannula. -

‡ Some hemolysis with possible resultant inaccuracy in dye measurement. 
the dye method. The only support for Asmussen's conclusions comes from certain sporadic experiments in which the volumes by the monoxide method greatly exceeded those by the dye method. Asmussen used a large rebreathing chamber (10-liter capacity) for the administration of carbon monoxide, and did not measure or otherwise correct for residual gas. Our own experience with a large rebreathing apparatus indicates that the amount of residual carbon monoxide is most variable, and is often large. If not corrected, this error would therefore make the blood volume by the carbon monoxide method larger than it should be by a variable amount. Neglect of this fact may account for some of Asmussen's aberrant findings. The use of an extrapolated value for dye concentration in some studies but not in others may have been another contributory factor.

Various workers have found larger blood volumes with dye methods than with the carbon monoxide method (5 to 10). Thus Smith, Belt, Arnold, and Carrier (6), using brilliant vital red and carbon monoxide alternately every 1 to 3 days, found the blood volume in man about 30 per cent higher by the dye than by the carbon monoxide method. The average blood volume of normal man by the carbon monoxide method in 20 experiments was $71 \pm 5 \mathrm{cc}$. per $\mathrm{kgm}$. body weight, while in 20 comparable determinations by the dye method it was $93 \pm 8 \mathrm{cc}$. per $\mathrm{kgm}$. body weight. Their methods differed from ours in numerous technical details. For example, only 4 minutes were allowed for mixing time and 10 . minutes for the absorption and distribution of carbon monoxide, although 2 to 3 times as much gas as that given in our experiments was administered. McIntosh (10) reported similar results in 10 normal infants, the mean blood volume by the monoxide method being $71 \pm 2$ cc. per kgm. body weight, that by the dye method $93 \pm 10 \mathrm{cc}$. per $\mathrm{kgm}$. body weight. His technics were similar to those employed by Smith and his associates, except that the determinations were done simultaneously. Bazett and his associates (5) found that the average blood volume measured with Congo red dye exceeded the average volume with the monoxide method by some 8 per cent.

In dogs, Lee, Carrier, and Whipple found a
TABLE IV

Average whole blood, cell, and plasma volumes by Evans blue dye method and by carbon monoxide method, expressed in terms of cubic centimeters per kilogram body weight Data derived from Tables I and II

\begin{tabular}{|c|c|c|c|c|c|c|}
\hline & \multicolumn{2}{|c|}{ Blood volume } & \multicolumn{2}{|c|}{ Cell volume } & \multicolumn{2}{|c|}{ Plasma volume } \\
\hline & $\begin{array}{c}\text { Dye } \\
\text { method }\end{array}$ & $\begin{array}{c}\text { CO } \\
\text { method }\end{array}$ & $\begin{array}{c}\text { Dye } \\
\text { method }\end{array}$ & $\begin{array}{c}\text { Co } \\
\text { method }\end{array}$ & $\begin{array}{c}\text { Dye } \\
\text { method }\end{array}$ & $\underset{\text { method }}{\mathrm{CO}}$ \\
\hline Human subjects & & & $c c$. & $\propto$. & c. & $\infty$ \\
\hline $\begin{array}{c}\text { (9) } \\
\text { Dogs (16) }\end{array}$ & $\begin{array}{l}80.5 \pm 8.6 \\
95.2 \pm 12.4\end{array}$ & $\begin{array}{l}80.2 \pm 5.5 \\
95.4 \pm 12.0\end{array}$ & $\begin{array}{l}35.0 \\
39.8\end{array}$ & $\begin{array}{l}34.9 \\
40.3\end{array}$ & $\begin{array}{l}45.5 \\
55.4\end{array}$ & $\begin{array}{l}45.3 \\
55.1\end{array}$ \\
\hline
\end{tabular}

quite similar difference between the results of the carbon monoxide method and of the dye method $(7,8)$. For example, converting the results of a typical experiment of theirs into terms comparable with our own, in 14 dogs the average blood volume was $87 \pm 4 \mathrm{cc}$. per $\mathrm{kgm}$. of body weight, measured by carbon monoxide, while by the dye method, it was $104 \pm 4 \mathrm{cc}$. per $\mathrm{kgm}$. of body weight. Smith, Arnold, and Whipple (9) obtained similar results, and found that the viviperfusion method gave values for cell mass comparable to the carbon monoxide values rather than to those given by the dye method. More recently, Hahn and his associates (28) found that a new method for cell volume based on the use of radioactive iron in erythrocytes gave values similar to those obtained by the viviperfusion method, and therefore comparable to those given by the carbon monoxide method. The volumes were definitely smaller than those obtained by these same workers with brilliant vital red dye.

The results obtained by these investigators are clearly inconsistent with our own observations. Their absolute values by the carbon monoxide method in man are a little lower than ours, while their values for plasma volume by the brilliant vital red method are much higher than those obtained by us with the Evans blue dye, T1824. This discrepancy may possibly be in part ascribed to the difference between the 2 dyes, since their volumes of distribution are only approximately identical (29). Differences in technic of administration may also play a rôle. The use by us of a single 10-minute blood sample in calculating the plasma volume tends to make our values higher than would a 4-minute sample, so this cannot explain the fact that our values are smaller than theirs. Gregerson (30), reviewing 
in 1938 the errors encountered in the use of brilliant vital red, concluded that failure to recognize these difficulties renders almost all previous blood volume studies with this technic suspect. Congo red is now known to be an unsatisfactory dye for blood volume estimations (31). Certainly in comparing results obtained with modern technics, using T1824, with older work using brilliant vital red or other dyes, it is reasonable, other things being equal, to attach greater weight to the more recent work.

Although the blood volume values calculated from the apparent volumes of distribution of carbon monoxide and of dye are frequently numerically identical, it does not necessarily follow that this common figure therefore represents the true blood volume. Numerical coincidence in normal subjects does not even prove that the 2 methods are measuring exactly the same physiological compartment, since errors due to one cause with the monoxide method may well chance to be numerically equal to errors due to some quite different cause in the dye method. There is evidence, discussed elsewhere $(32,3)$, that dye measures a space much larger than the vascular space, owing to loss of dye to lymphatics and elsewhere. Insofar as the carbon monoxide method gives a comparable or higher value for plasma volume, it follows that carbon monoxide also may be distributed over a space larger than the vascular space. There is good reason for believing that there is no appreciable loss of carbon monoxide to myoglobin of muscle (summarized in (3)). The fact that our carbon monoxide and dye measurements bore the same relationship to one another in splenectomized and in normal animals suggests that carbon monoxide is not lost to the spleen; otherwise some systematic difference between measurements in normal and in splenectomized animals might be expected. The possibility exists that carbon monoxide in red cells of the circulating blood may. shift into red cells of the bone marrow, resulting in too large a value for blood volume.

In general, it may be concluded that neither method has been shown regularly to measure absolute volume. Their reliability as relative measures of blood volume must, be assessed by studying their variations under circumstances in which blood volume is known to vary. This problem is dealt with elsewhere (3).

\section{SUMMARY}

1. Measurements of blood volume in normal men and dogs by the distribution of T1824 and of carbon monoxide, given simultaneously, were often but not always found to be numerically equivalent.

2. In some subjects, the dye method gave the larger values, in others the carbon monoxide method. Average values for blood volume per unit body weight were almost identical by the 2 methods.

3. There is no proof at present that either method regularly measures absolute blood volume.

The authors are indebted to Professor John Fulton for the use of the facilities of the Laboratory of Physiology of the Yale University School of Medicine.

\section{BIBLIOGRAPHY}

1. Rawson, R. A., The binding of T-1824 and structurally related diazo dyes by the plasma proteins. Am. J. Physiol., 1943, 138, 708.

2. Hahn, P. F., Balfour, W. M., Ross, J. F., Bale, W. F., and Whipple, G. H., Red cell volume circulating and total as determined by radio iron. Science, 1941, 93, 87.

3. Hopper, J., Jr., Winkler, A. W., and Elkinton, J. R., Simultaneous measurements of the blood volume in man and dog by means of the blue dye, T1824, and by means of carbon monoxide. II. Under abnormal conditions, including secondary shock. J. Clin. Invest., 1944, 23, 636.

4. Asmussen, E., Determination of blood volume by carbon monoxide method. Acta Physiol. Scandinav., 1942, 3, 156.

5. Bazett, H. C., Sunderman, F. W., Maxfield, M. E., and Scott, J. C., Comparison of estimates of blood volume made by congo red and by carbon monoxide. Am. J. Physiol., 1940, 129, 309P.

6. Smith, H. P., Belt, A. E., Arnold, H. R., and Carrier, E. B., Blood volume changes at high altitude. Am. J. Physiol., 1924-25, 71, 395.

7. Carrier, E. B., Lee, F. W., and Whipple, G. H., I. Determination of plasma and hemoglobin volumes after unit hemorrhages under controlled experimental conditions. Am. J. Physiol., 1922, 61, 138.

8. Lee, F. W., Carrier, E. B., and Whipple, G. H. II. Simultaneous determinations of plasma and hemoglobin volumes (Influence of fluids by mouth and vigorous exercise). Am. J. Physiol., 1922, 61, 149. 
9. Smith, H. P., Arnold, H. R., and Whipple, G. H., Blood volume studies. VII. Comparative values of Welcker, carbon monoxide and dye methods for blood volume determinations. Accurate estimation of absolute blood volume. Am. J. Physiol.; $1921,56,336$.

10. McIntosh, R., The determination of circulating blood volume in infants by the carbon monoxide method. J. Clin. Invest., 1929, 7, 203.

11. Hahn, P. F., Bale, W. F., and Bonner, J. F., Jr., Removal of red cells from the active circulation by sodium pentobarbital. Am. J. Physiol., 1943, 138, 415.

12. Jarcho, L. W., The effect of nembutal-ether anesthesia upon blood concentration. Am. J. Physiol., 1943, 138, 458.

13. Eisenman, A. J., Method for anaerobic defibrination of blood. J. Biol. Chem., 1926-27, 71, 607.

14. Eisenman, A. J., MacKenzie, L. B., and Peters, J. P., Protein and water of serum and cells of human blood, with a note on the measurement of red blood cell volume. J. Biol. Chem., 1936, 116, 33.

15. Gibson, J. G., 2nd, and Evelyn, K. A., Clinical studies of the blood volume. IV. Adaptation of the method to the photoelectric microcolorimeter. J. Clin. Invest., 1938, 17, 153.

16. Price, P. B., and Longmire, W. P., The use of T-1824 in plasma volume determinations. Bull. Johns Hopkins Hosp., 1942, 71, 51.

17. Phillips, R. A., A method for the determination of the blue dye T-1824 in plasma. J. Exper. Med., 1943, 77, 421.

18. King, B. G., Cole, K. S., and Oppenheimer, E. T., Disappearance curves of the dye T-1824 after its injection into the blood stream. Am. J. Physiol., 1943, 138, 636.

19. Gibson, J. G., 2nd, and Evans, W. A., Jr., Clinical studies of the blood volume. II. The relation of plasma and total blood volume to venous pressure, blood velocity rate, physical measurements, age and sex in ninety normal persons. J. Clin. Invest., 1937, 16, 317.

20. Van Slyke, D. D., and Robscheit-Robbins, F. S.,
The gasometric determination of small amounts of carbon monoxide in blood and its application to blood volume studies. J. Biol. Chem., 1927, 72, 39.

21. Ziegler, E. E., The intravenous administration of oxygen. J. Lab. and Clin. Med., 1941, 27, 223.

22. Van Slyke, D. D., and Hiller, A., Gasometric determination of hemoglobin by the carbon monoxide capacity method. J. Biol. Chem., 1928, 78, 807.

23. Chang, H. C., and Harrop, G. A., Jr., The determination of the circulating blood volume with carbon monoxide. J. Clin. Invest., 1928, 5, 393.

24. Arnold, H. R., Carrier, E. B., Smith, H. P., and Whipple, G. H., Blood volume studies. V. The carbon monoxide method-its accuracy and limitations. Am. J. Physiol., 1921, 56, 313.

25. Wennesland, R., A new method for the determination of carbon monoxide in blood. Acta Physiol. Scand., 1940, 1, 49.

26. Christman, A. A., Block, W. D., and Schultz, J., Determination of carbon monoxide in air. Indust. and Engin. Chem., 1937, 9, 153.

27. Sendroy, J., Jr., and Liu, S. H., Gasometric determination of oxygen and carbon monoxide in blood. J. Biol. Chem., 1930, 89, 133.

28. Hahn, P. F., Ross, J. F., Bale, W. F., Balfour, W. M., and Whipple, G. H., Red cell and plasma volumes (circulating and total) as determined by radio iron and by dye. J. Exper. Med., 1942, 75, 221.

29. Dawson, A. B., Evans, H. M., and Whipple, G. H., Blood volume studies. III. Behavior of large series of dyes introduced into the circulating blood. Am. J. Physiol., 1920, 51, 232.

30. Gregersen, M. I., An analysis of colorimetric methods in relation to plasma volume determinations. $\mathrm{J}$. Lab. and Clin. Med., 1938, 23, 423.

31. Lindhard, J., Dye-methods for determining the bloodvolume tested in vitro. Am. J. Physiol., 1926, 76, 497.

32. Peters, J. P., Serum proteins in health and disease. J. Mt. Sinai Hosp., 1942, 9, 127.

33. Gilder, H., Müller, O., and Phillips, R., Mixing time of T-1824 in blood. Am. J. Physiol., 1940, 129, P362. 